\title{
Erratum: Identification of novel transcription factors regulating secondary cell wall formation in Arabidopsis
}

\section{Hua Cassan-Wang, Nadia Goué, Mohammed N. Saidi, Sylvain Legay, Pierre Sivadon, Deborah Goffner and Jacqueline Grima-Pettenati*}

Laboratoire de Recherche en Sciences Végétales, UMR5546, Centre National de la Recherche Scientifique, Université Toulouse III (UPS), Toulouse, France

*Correspondence: grima@Irsv.ups-t/se.fr

Edited and reviewed by:

Soren K. Rasmussen, University of Copenhagen, Denmark

Keywords: secondarycellwall, xylem, fibers, transcription factors, arabidopsis, lignin, co-expression, biofuels

\section{A commentary on}

Identification of novel transcription factors regulating secondary cell wall formation in Arabidopsis

by Cassan-Wang, H., Goué, N., Saidi, M. N., Legay, S., Sivadon, P., Goffner, D., et al. (2013). Front. Plant. Sci. 4:189. doi: 10.3389/fpls.2013.00189

After our article was published on line, we noticed that a typographical mistake occured in the name of an Arabidopsis mutant:

p 6, in the results, last paragraph of the section « phenotypes of the TF T-DNA mutant or RNAi transgenic lines $\gg$, One should read $h b 5$ instead of $h b 15$
Here is the corrected text

The overall growth behavior of the mutants did not differ significantly from the controls, except the bolting and flowering time were altered in three of the mutant lines. Hypolignified blh6 and zinc finger lines bolted and flowered earlier than controls (Figures 5A,C) whereas the hyperlignified $\boldsymbol{h} \boldsymbol{b} 5$ line exhibited delayed bolting and flowering (Figures 5B,C). In addition, $\boldsymbol{h} \boldsymbol{b} 5$ mutants exhibited aerial rosettes at the base of the lateral inflorescence branches instead of growing cauline leaves as in wild-type plants (Figure 5D).

Conflict of Interest Statement: The authors declare that the research was conducted in the absence of any commercial or financial relationships that could be construed as a potential conflict of interest.

Received: 06 May 2014; accepted: 14 May 2014; published online: 03 June 2014.

Citation: Cassan-Wang H, Goué N, Saidi MN, Legay S, Sivadon P, Goffner D and Grima-Pettenati J (2014) Erratum: Identification of novel transcription factors regulating secondary cell wall formation in Arabidopsis. Front. Plant Sci. 5:246. doi: 10.3389/fpls.2014.00246

This article was submitted to Plant Biotechnology, a section of the journal Frontiers in Plant Science.

Copyright (c) 2014 Cassan-Wang, Goué, Saidi, Legay, Sivadon, Goffner and Grima-Pettenati. This is an openaccess article distributed under the terms of the Creative Commons Attribution License (CC BY). The use, distribution or reproduction in other forums is permitted, provided the original author(s) or licensor are credited and that the original publication in this journal is cited, in accordance with accepted academic practice. No use, distribution or reproduction is permitted which does not comply with these terms. 